\title{
Prenatal diagnosis of conjoined twins: four cases in a prenatal center
}

\author{
Yapışık ikizlerin prenatal tanısl: bir prenatal tanı ünitesinin dört olgusu
}

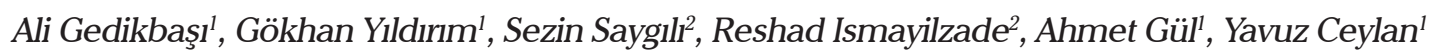 \\ ' Department of Obstetrics and Gynecology, Perinatology Unit, Istanbul Bakrrköy Maternity and Children Diseases Hospital, Istanbul, Turkey \\ ${ }^{2}$ Department of Obstetrics and Gynecology, Istanbul Bakirköy Maternity and Children Diseases Hospital, Istanbul, Turkey
}

\section{Abstract}

Objective: To assess the findings in conjoined twins diagnosed prenatally.

Material and Methods: Between January 2002 and June 2009, we reviewed the database and medical records of 857 twin pregnancies, including 140 monochorionic twins. Nineteen monochorionic-monoamniotic twin pregnancies were detected, four of which were complicated by conjoined twins.

Results: Of these 4 cases, 2 were complicated by thoracopagus and one had thoraco-omphalopagus; these three cases underwent termination at 16,11 , and 19 weeks gestation, respectively. The last case was diagnosed as a pygopagus tetrapus parasitic twin at 28 weeks gestation. The family decided to continue the pregnancy, and achieved a successful outcome with elective surgery postpartum.

Conclusion: Conjoined twins are an uncommon and complex complication of monozygotic gestations, which is associated with high perinatal mortality. The early prenatal diagnosis of conjoined twins allows improved counseling about the management options, including maintenance of pregnancy with surgery after delivery or termination of pregnancy. (J Turkish-German Gynecol Assoc 2010; 11: 174-7)

Key words: Conjoined twins, prenatal diagnosis

Received: 22 December, 2009

Accepted: 11 February, 2010

\section{Introduction}

Conjoined twins are defined by the conjoined body area, and result from incomplete monozygotic twinning. The incidence of conjoined twins is estimated at $1 \%$ of monozygotic twinning or 1/200,000 live births (1). Over the last decade, the widespread use of assisted reproductive techniques has decreased the rate of monochorionic twins, and consequently may have changed the prevalence of conjoined twins $(2,3)$. Approximately $75 \%$ of conjoined twins are females (4). Conjoined twins have an anomaly of duplication in singlezygote conceptions which is thought to occur because of splitting and incomplete separation of the inner cell mass at 13-15 days post-fertilization. Forty percent of conjoined twins are stillborn and another 30\% die during the 1st day of life (5). The prenatal diagnosis of conjoined twins began in 1976 (6). There is no doubt that the accurate and early diagnosis of fetal malformations will affect management and perinatal out-
Özet

Amaç: Prenatal olarak tanısı konmuş yapışık ikiz olgularında bulguların değerlendirilmesi.

Gereç ve Yöntemler: Ocak 2002 ile Haziran 2009 tarihleri arasında, 140 monokoryonik ikiz olgusunu da içeren, toplam 857 ikiz olgusunun verileri ve tıbbi kayıtlan değerlendirildi. Toplam 19 monokoryonikmonoamniotik ikiz olgusunun dört tanesi yapışık ikiz olarak değerlendirildi.

Bulgular: $\mathrm{Bu} 4$ olgunun ikisi torakopagus ve bir tanesi torakoomfalopagus ile komplike olup, sırası ile 16,11 ve 19 . gebelik haftalarında gebelik sonlandırması uygulanmıstır. Son olgu bir pygopagus tetrapus parazitik ikiz olgusu olup 28. gebelik haftasında tanısı konmuştur. Gebeliğin devamına karar veren ailenin, elektif postpartum cerrahi ile başarılı sonucu alınmıştır.

Sonuç: Yapışık ikizler monozigot ikizlerin ender saptanan komplike bir gelişimi olup, yüksek perinatal mortalite oranları göstermektedir. Yapışık ikizlerin erken tanısı, ebeveynlere gebeliğin devamı ve doğum sonrası cerrahi seçenekleri ile gebeliğin sonlandırılması konusunda erken bilgilendirme olanağı sağlamaktadır.

(J Turkish-German Gynecol Assoc 2010; 11: 174-7)

Anahtar kelimeler: Yapışık ikizler, prenatal tanı

Geliş Tarihi: 22 Aralık 2009

Kabul Tarihi: 11 Şubat 2010

comes. We present four cases of conjoined twins (thoracoomphalopagus, thoracopagus, pygopagus tetrapus parasitic twins, and omphalopagus) detected in the first, second, and third trimesters using two-dimensional (2D) color Doppler ultrasound and three-dimensional (3D) ultrasound for the last case. Case 3 has previously been published with the diagnosis of a pygopagus tetrapus parasitic twin (7).

\section{Material and Methods}

All twin pregnancies admitted, followed, and delivered in our maternal-fetal medicine unit between January 2002 and June 2009 were recorded in medical charts and our computer database. A careful ultrasound evaluation was performed to identify or verify fetal details. Pregnancy and ultrasonographic findings were also entered into the database.

Twin pregnancies were divided into two groups: dichorionic (DC) and monochorionic (MC) pregnancies. MC 
twins were also sub-grouped as diamniotic and monoamniotic twins. Prenatal sonographic details were evaluated with related abnormalities depending on chorionicity and fetal development. Ultrasonographic examinations were performed transabdominally or transvaginally by one of four experienced maternal-fetal medicine physician sonographers using a Sonoline-G50 (TM-Siemens, multifrequency convex transducer 2.0-7.0 MHz; Issaquah, WA, USA) and Voluson 730 Expert (TMGE Healthcare, multifrequency convex transducer $2.0-7.0 \mathrm{MHz}$, a $2-7-\mathrm{MHz}$ convex transducer and a $4-8-\mathrm{MHz}$ micro-4D convex real-time 4D-transducer; Milwaukee, WI, USA).

\section{Results}

During the study period, our database consisted of 857 twin pregnancies. We excluded $672 \mathrm{DC}$ pregnancies with $140 \mathrm{MC}$ twins. One hundred and two MC twins had regular development or additional malformations and 32 cases had twin-twin transfusion syndrome (TTTS). Nineteen cases were diagnosed as MC monoamniotic twin pregnancies, four of which were complicated by conjoined twins and two cases had acardiac twin development. Forty-five DC and MC twins were excluded because of an incomplete database.

\section{Case 1}

A 27-year-old gravida 1 para 0 was referred at 16 weeks 3 days gestation with a presumptive diagnosis of conjoined twins. On referral,the 2D transabdominal ultrasound demonstrated a monochorionic, monoamniotic twin gestation complicated by thoracopagus. Observations of the thoracic and abdominal cavities in transverse planes clearly demonstrated that the twins were joined over an area that extended from the central abdomen (omphalopagus) to the lower aspect of the thorax (thoracopagus). In view of the poor fetal prognosis, the family opted for pregnancy termination.

\section{Case 2}

A 19-year-old gravida 1 para 0 at 19 weeks gestation was registered for care in our prenatal clinic in the second trimester. Sonography revealed the presence of a monochorionic, monoamniotic twin pregnancy. The twins, facing each other, were joined at the thoracic level with a final diagnosis of thoracopagus (Figure 1). An elective abortion was performed after counseling.

\section{Case 3}

A 30-year-old multigravida was referred to our maternal-fetal unit for evaluation of polyhydramnios at 28 weeks gestation. A sonographic examination revealed a single fetus and polyhydramnios with an amniotic fluid index of $30 \mathrm{~cm}$. The fetus had a normal head, spine, thorax, abdomen, two upper and two lower limbs, and two relatively well developed rudimentary parasitic lower limbs in the sacral region. The lower limbs of the autosite moved freely, but no movement was detected in the parasite. The parasite contained irregular lower limbs and a left foot with three toes. Short and deformed long bones were also present in the parasitic limbs. A cesarean section was performed at 38 weeks gestation. A live female infant weighing
$3600 \mathrm{~g}$ was delivered. The parasitic lower limbs were totally excised. The final diagnosis was a pygopagus tetrapus parasitic twin (Figure 2). The post-operative period was uneventful and the newborn was discharged in healthy condition. Postnatal follow-up was uneventful after 9 months (7).

\section{Case 4}

A 25 year-old gravida 1 para 0 was referred to our perinatology clinic because of a monochorionic, monoamniotic twin pregnancy. An ultrasound examination revealed conjoined twins, each with a crown-rump length of $44 \mathrm{~mm}$, consistent with 11 weeks 3 days gestation. The twins were joined at the abdomen. An omphalopagus conjoined twin pregnancy was diagnosed with 3D ultrasound (Figure 3). After counseling, the family opted for an elective abortion.

\section{Discussion}

Classically, conjoined twins have been reported to arise at around 12-13 days post-conception from a single blastocyst

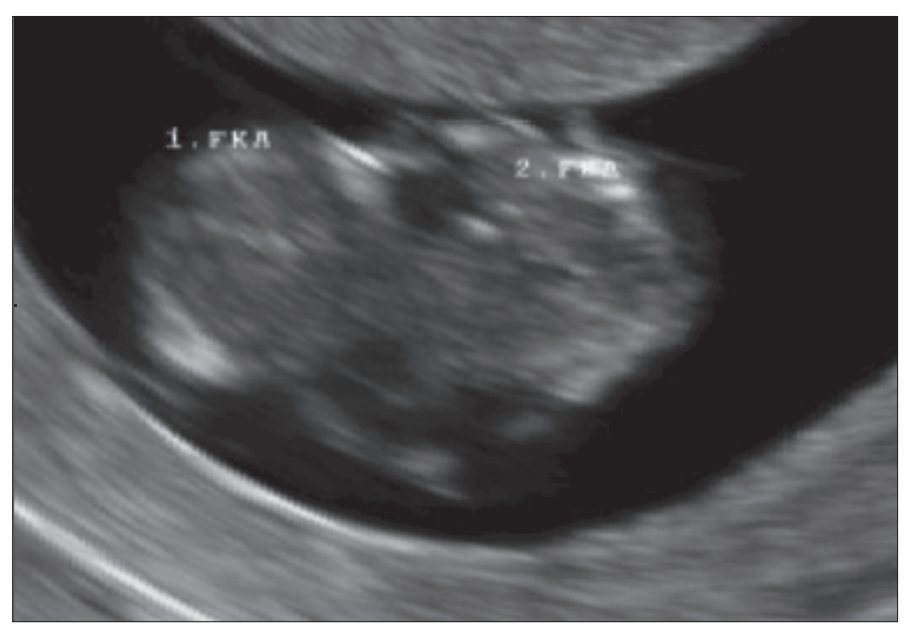

Figure 1. Diagnosis of case 2 with thoracopagus

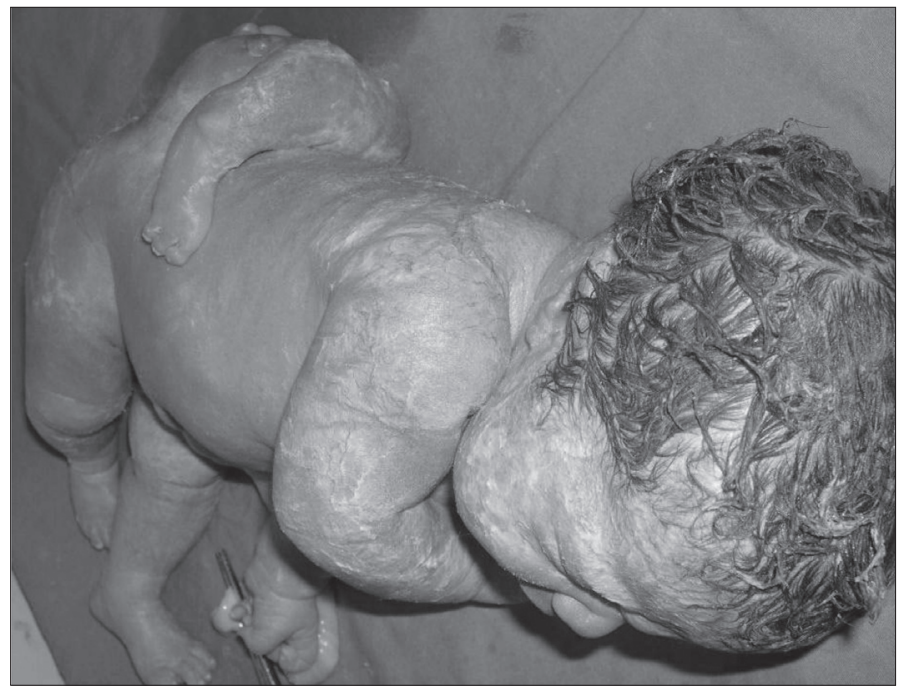

Figure 2. Postnatal final diagnosis of case 3 as pygopagus tetrapus parasitic twin 


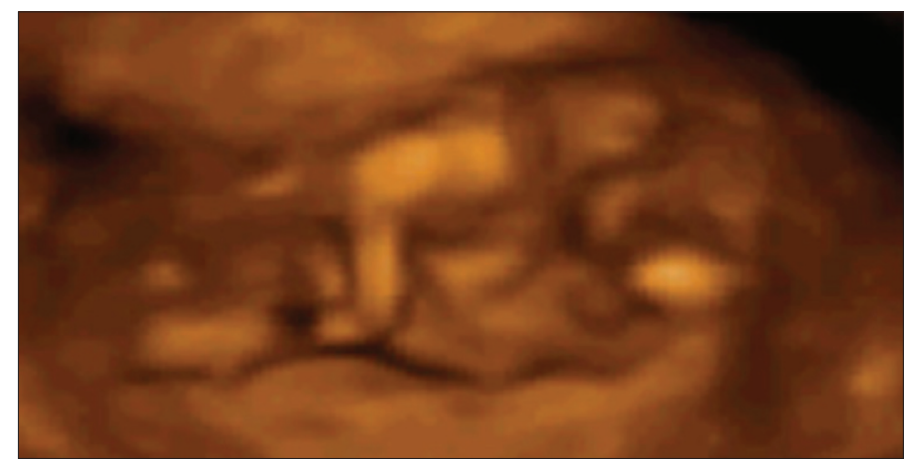

Figure 3. 3D image of case 3 with omphalopagus

that had undergone incomplete division of the embryonic cell mass (4). Embryologic studies have shown that this extraordinary anomaly could develop from fusion of the two separate embryonic discs. Conjoined twins are classified according to the site of fusion and are always joined at identical anatomic points (Table 1). The combination of different types can occur, but the most frequently seen types include thoracopagus (20-40\%), omphalopagus (18-33\%), and parapagus (28\%). Rachipagus is the rarest type of conjoined twins with an incidence of approximately $2 \%(8,9)$.

The sonographic diagnosis of conjoined twins was first reported by Wilson et al. (6). Conjoined twins have been diagnosed in the first trimester with both transabdominal and transvaginal sonography $(10,11)$. According to Hill (12), the earliest prenatal suspicion of conjoined twins can arise at 7 weeks gestation. Because all conjoined twins are monochorionic and monoamniotic, the level of suspicion should increase when only one yolk sac is noted alongside two embryos in very early pregnancies or there are separating membranes not seen by ultrasound examination at any stage of pregnancy.

Non-operative management in cases with complex cardiac union, and emergency separation in cases with cardiac instability or additional structural anomalies warranting immediate surgical intervention and planned elective separation are ideally carried out between 2 and 4 months of age. Emergency separation carries a mortality rate of $71 \%$, whereas the survival rate for elective separation is $80 \%$ (13). In cases with extensive cardiac or cerebral fusion, or when the anticipated severity of deformity following separation is unacceptable, the parents may desire to terminate the pregnancy (14). Although our cases with the diagnosis of separated hearts and thoracopagus and/ or omphalopagus (cases 1, 2, and 4) had a better prognosis, the parents elected termination.

Although the prognosis for all types of conjoined twins is extremely poor, a careful anatomic and vascular mapping to determine the extent of organ sharing is of vital importance (15). First-trimester transvaginal ultrasonography in combination with color Doppler and 3D ultrasound are important advances that allow for the early diagnosis of conjoined twins. The data obtained by combining these complementary modalities may also be of prognostic value (16). Additionally, the accurate prenatal diagnosis of conjoined twins can be performed with these modalities as early as 10 weeks gestation $(17,18)$. Cases with false-positive diagnoses in the first trimester have been documented; there-
Table 1. Classification of conjoined twins with incidence

\begin{tabular}{|c|c|}
\hline Classification & Incidence (\%) \\
\hline \multicolumn{2}{|l|}{ Ventral union } \\
\hline $\begin{array}{l}\text { Cephalopagus. Fusion from top of } \\
\text { head to umbilicus. Each twin has } 2 \\
\text { extremities and lower abdomen and pelvis } \\
\text { are separated. }\end{array}$ & 11 \\
\hline $\begin{array}{l}\text { Thoracopagus. Twins are located face to } \\
\text { face, with fused thoraces and shared heart } \\
\text { or single interatrial vessel. }\end{array}$ & $20-40$ \\
\hline $\begin{array}{l}\text { Omphalopagus. Twins have similar fusion } \\
\text { to thoracopagus without shared heart or } \\
\text { interatrial vessel. }\end{array}$ & $18-33$ \\
\hline $\begin{array}{l}\text { Ischiopagus. These twins share a large } \\
\text { conjoined pelvis and are more commonly } \\
\text { joined end to end. External genitalia and } \\
\text { anus are always shared. }\end{array}$ & $6-11$ \\
\hline \multicolumn{2}{|l|}{ Dorsal union } \\
\hline $\begin{array}{l}\text { Craniopagus. Twins are joined by any } \\
\text { portion of the skull except the face and } \\
\text { foramen magnum. The bony cranium, } \\
\text { meninges and brain are shared. }\end{array}$ & 2 \\
\hline $\begin{array}{l}\text { Pygopagus. Twins have fused } \\
\text { sacrococcygeal and perineal regions, } \\
\text { typically with shared anus but separate } \\
\text { rectums. The spinal cord may be shared. }\end{array}$ & $18-28$ \\
\hline $\begin{array}{l}\text { Rachipagus. Twins have dorsal fusion } \\
\text { above the sacrum. }\end{array}$ & Rare \\
\hline \multicolumn{2}{|l|}{ Lateral union } \\
\hline $\begin{array}{l}\text { Parapagus. Twins have side-by-side } \\
\text { connection with shared pelvis and } \\
\text { variable cephalad sharing defined } \\
\text { as follows: }\end{array}$ & 28 \\
\hline $\begin{array}{l}\text { - Dithoracic parapagus: separate } \\
\text { thoraces and heads. }\end{array}$ & \\
\hline $\begin{array}{l}\text { - Dicephalic parapagus: separate } \\
\text { heads with fused thoraces. }\end{array}$ & \\
\hline $\begin{array}{l}\text { - Diprosopus parapagus: } 2 \text { faces on } \\
\text { the same side of single head. }\end{array}$ & \\
\hline From Winkler et al. (9) & \\
\hline
\end{tabular}

fore, an exact diagnosis should be made with caution (19). This technique may also provide images that are easier for parents to understand, which can help in decision making (20,21).

Parasitic twins are a rare form of conjoined twins and consist of an incomplete twin (parasite) attached to the fully developed body of the co-twin (autosite). Parasitic twins are classified (22) as (a) an externally attached parasitic twin, (b) an enclosed fetus in fetu, (c) an internal teratoma, or (d) an acardiac twin connected via the placenta. This was the only surviving case (case 3 ) in our study in which the parents made the decision to continue the pregnancy and a successful result was achieved. 
Conflict of interest

No conflict of interest is declared by authors.

\section{References}

1. Kaufman MH. The embryology of conjoined twins. Child's Nervous System 2004; 20: 508-25.

2. Cohen J, Elsner C, Kort H, Malter H, Massey J, Mayer MP, Wiemer $\mathrm{K}$. Impairment of the hatching process following IVF in the human and improvement of implantation by assisting hatching using micromanipulation. Hum Reprod 1990; 5: 7-13.

3. Apuzzio JJ, Ganesh UV, Chervenak J, Sama JC. Prenatal diagnosis of dicephalous conjoined twins in a triplet pregnancy. Am J Obstet Gynecol 1988; 159: 1214-5.

4. Machin GA, Keith LG, Bamforth F (edts). An Atlas of Multiple Pregnancy: Biology and Pathology. Parthenon Publishing Group. New York; 1999

5. Oleszczuk JJ, Oleszczuk AK. In Blickstein I, Keith LG, Keith DM, Teplica D, editors. Multiple Pregnancy,Epidemiology, Gestation and Perinatal Outcome, 2nd edition, London, England: Informa Healthcare; 2005. p. 233-45.

6. Wilson RL, Cetrulo CL, Shaub MS. The prepartum diagnosis of conjoined twins by the use of diagnosis of conjoint twins by the use of diagnostic ultrasound. Am J Obstet Gynecol 1976; 126: 737.

7. Gul A, Aslan H, Ceylan Y. Prenatal diagnosis of pygopagus tetrapusparasitic twin: case report. BMC Pregnancy Childbirth 2004; 4: 13

8. Spencer R. Anatomic description of conjoined twins: a plea for standardized terminology. J Pediatr Surg 1996, 31: 941-4.

9. Winkler N, Kennedy A, Byrne J, Woodward P. The imaging spectrum of conjoined twins. Ultrasound Quarterly 2008; 24: 249-55.

10. Jones KL. In Jones KL (edt). Smith's Recognizable Patterns of Human Malformation 6th edition, Elsevier Saunders. Philadelphia; 2006.
11. Logrono R, Garcia-Lithgow C, Harris C, Kent M, Meisner L. Heteropagus conjoined twins due to fusion of two embryos: report and review. Am J Med Genet 1997; 73: 239-43.

12. Hill LM. The sonographic detection of early first-trimester conjoined twins. Prenat Diagn 1997; 17: 961-3.

13. Spitz L, Kiely EM. Experience in the management of conjoined twins. Br J Surg 2002; 89: 1188-92.

14. Spitz L. Conjoined twins. Review. Prenat Diagn 2005; 25: 814-9.

15. Skupski DW, Streltzoff J, Hutson JM, Rosenwaks Z, CohenJ, Chervenak FA. Early diagnosis of conjoined twins in triplet pregnancy after in vitro fertilization and assisted hatching. J Ultrasound Med 1995; 14: 611-5.

16. Bonilla-Musoles F, Raga F, Bonilla F, Blanes J, Osborne NG. Early diagnosis of conjoined twins using two-dimensional color Doppler and three-dimensional ultrasound. J Natl Med Assoc 1998; 90: 552-6.

17. Maymon R, Halperin R, Weinraub Z, Herman A, Schneider D. Three-dimensional transvaginal sonography of conjoined twins at 10 weeks: a case report. Ultrasound Obstet Gynecol 1998; 11: 292-4.

18. Bega G, Wapner R, Lev-Toaff A, Kuhlman K. Diagnosis of conjoined twins at 10 weeks using three-dimensional ultrasound: a case report. Ultrasound Obstet Gynecol 2000; 16: 388-90.

19. Usta IM, Awwad JT. A false positive diagnosis of conjoined twins in a triplet pregnancy: pitfalls of first trimester ultrasonographic prenatal diagnosis. Prenat Diagn 2000; 20:169-70.

20. Wataganara T, Sutanthaviboon A, Ngerncham S, Vantanasiri C. Three-dimensional power Doppler in the diagnosis and surgical management of thoraco-omphalopagus conjoined twins. Ultrasound Obstet Gynecol 2008; 32: 236-8.

21. Bornstein E, Santos R, Timor-Tritsch IE, Monteagudo A. "Brothers in Arms": 3-Dimensional Sonographic Findings in a First-Trimester Thoraco-Omphalopagus Conjoined Twin Pair. J Ultrasound Med 2009; 28: 97-9.

22. Spencer R. Parasitic conjoined twins: external, internal (fetuses in fetu and teratomas), and detached (acardiacs). Clin Anat 2001; 14: 428-44.

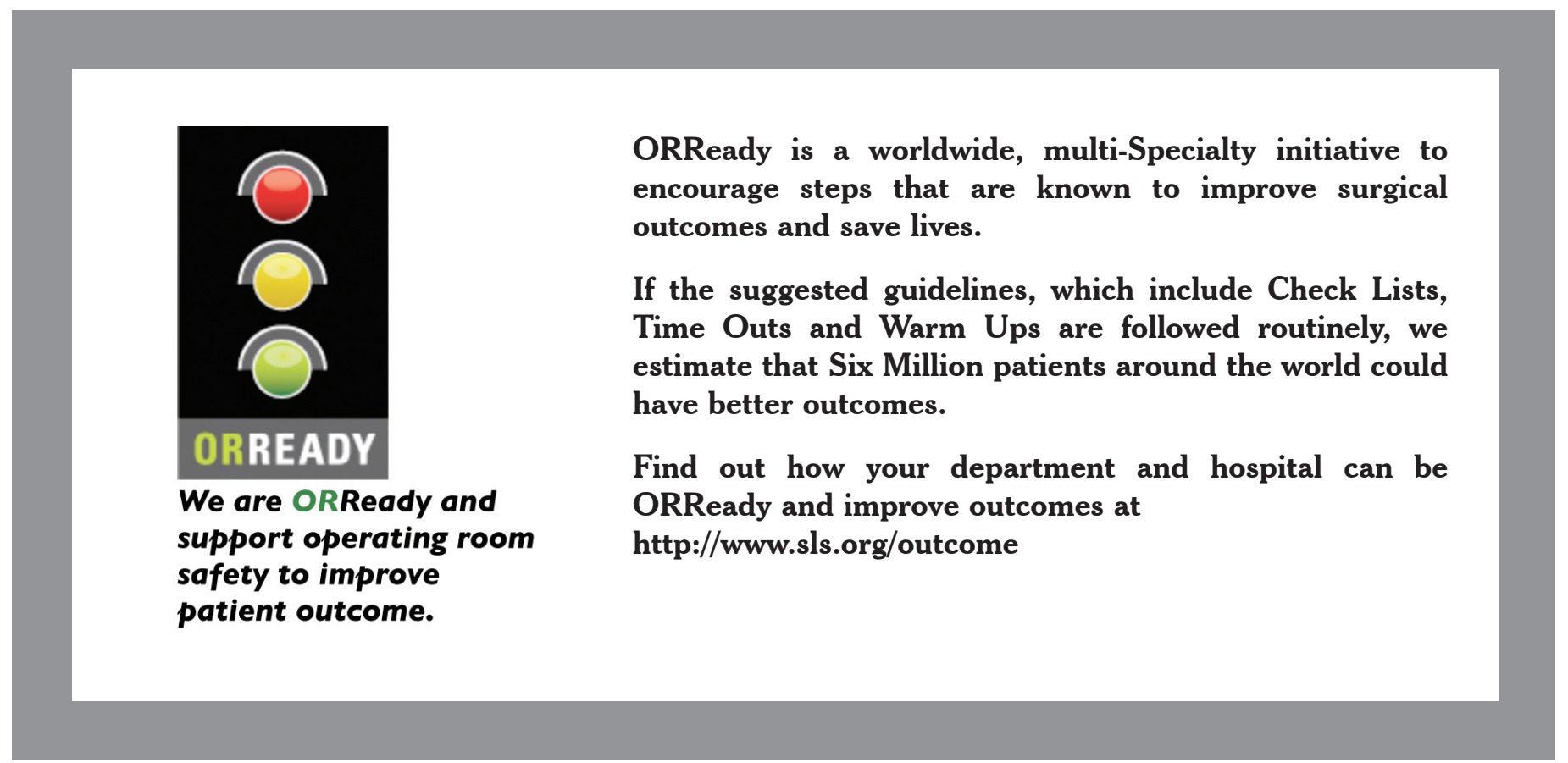

